\title{
Antigen-Specific B-Cell Responses by Neonatal Calves After Early Vaccination ${ }^{1}$
}

\author{
M. R. Foote, ${ }^{\star 2}$ B. J. Nonnecke, $\dagger^{3}$ D. C. Beitz, ${ }^{*}$ and W. R. Watersł \\ *Nutritional Physiology Group, Department of Animal Science, lowa State University, 313 Kildee Hall, Ames 50011 \\ †Periparturient Diseases of Cattle Research Unit, and \\ ¥Bacterial Diseases of Livestock Research Unit, USDA, ARS, National Animal Disease Center, 2300 Dayton Ave., Ames, IA 50010-0070
}

\begin{abstract}
The objective of this research was to evaluate the effects of early vaccination on the phenotype (i.e., activation marker expression) and functional capacity of $B$ cell populations in neonatal calves. In the first of 2 experiments, 6 calves were vaccinated with ovalbumin at 3 and 5 wk of age. Three of the 6 calves also were vaccinated with Mycobacterium bovis, strain bacillus Calmette-Guerin (BCG) at 3 wk of age. Mycobacterium bovis lipoarabinomannan-reactive $\mathrm{IgG}_{1}$ and $\mathrm{IgG}_{2}$ were detected in calf sera prior to vaccination, indicative of colostral transfer of maternal Ig cross-specific to BCG. Ovalbumin-specific $\mathrm{IgG}_{1}$ and $\mathrm{IgG}_{2}$ were not detected before vaccination. Vaccination of 3-wk-old calves with ovalbumin elicited antigen-specific $\mathrm{IgG}_{1}$ and $\mathrm{IgG}_{2}$ antibody responses that were amplified by secondary vaccination. Vaccination with BCG did not elicit a measurable antibody response. In the second experiment, 6 calves were vaccinated with ovalbumin at 3 and $5 \mathrm{wk}$ of age in addition to BCG at 3 wk of age. Lymph node cell populations stimulated with ovalbumin had decreased CD5, CD21, and CD40 expression and increased B-B2, $\mathrm{CD} 25$, and $\mathrm{CD} 80$ expression on $\mathrm{IgM}^{+}$cells. Stimulation of the same population with purified-protein derivative increased CD25 and CD80 expression on $\mathrm{IgM}^{+}$cells. Expression of activation molecules on ovalbumin- and purified protein derivative-stimulated $\mathrm{CD}^{+} \mathrm{IgM}^{+}$cells was similar to expression on the larger $\mathrm{IgM}^{+}$cell population. An increased expression of major histocompatibility class II on $\mathrm{CD}^{+} \mathrm{IgM}^{+}$cells after stimulation was the only exception. Interestingly, $\mathrm{IgM}^{+}$cells isolated from the superficial cervical lymph node draining the vacci-

\footnotetext{
Received April 16, 2007.

Accepted July 16, 2007.

${ }^{1}$ Names are necessary to report factually on available data; how-

${ }^{2}$ Current address: Dept. Anim. Sci., Cornell University, Ithaca,
} ever, the USDA neither guarantees nor warrants the standard of the product, and the use of the name by the USDA implies no approval of the product to the exclusion of others that may also be suitable. NY 14453

${ }^{3}$ Corresponding author: brian.nonnecke@ars.usda.gov
\end{abstract}

nation site, but not from the opposing cervical lymph node, responded to antigen stimulation in vitro. In conclusion, calves generated $\mathrm{B}$ cell responses to ovalbumin and BCG after vaccination. Additional studies are necessary to determine whether maternal immunologic experience transferred via colostral immunoglobulin inhibits production of mycobacteria-specific immunoglobulin production in the calf.

Key words: neonatal vaccination, B cell, Mycobacterium bovis strain bacillus Calmette-Guerin, preruminant calf

\section{INTRODUCTION}

High morbidity and mortality rates of neonatal calves due to infectious diseases cause substantial economic losses to producers. The bovine neonate is born agammaglobulinemic and relies on ingestion of colostrum for establishment of passive immunity. Although the importance of colostrum for passive transfer of maternal Ig in calves is well established, it has been suggested that maternal colostral-derived Ig compromises the elicitation of adaptive immune responses to vaccination (Husband and Lascelles, 1975; Aldridge et al., 1998). For example, neonatal calves fail to develop Ig responses to Brucella abortus if antigen-specific maternal Ig is present at the time of vaccination (Husband and Lascelles, 1975). Colostrum-deprived calves, however, produce relatively robust antibody responses to $B$. abortus. In addition, neonatal calves sensitized to ovalbumin (OVA; an antigen to which there was no maternal antibody) at birth mount humoral responses similar to older cattle, regardless of colostral status (Husband and Lascelles, 1975). Likewise, neonatal calves vaccinated with Mycobacterium bovis, strain bacillus Calmette-Guerin (BCG), fail to mount antigen-specific humoral responses; antigen-induced proliferative and functional capacities of $\mathrm{T}$ cells from vaccination calves, however, are similar to those of adults (Nonnecke et al., 2005). Cutaneous delayed-type hypersensitivity responses to intradermal administration of purified protein derivative (PPD) are similar in BCG vaccinated 
calves and adults as well, demonstrating the capacity of the bovine neonate to develop a vigorous cell-mediated immune response in vivo (Nonnecke et al., 2005). In addition, calves given a bovine viral diarrhea virus vaccine develop antigen-specific $\mathrm{CD}^{+}, \mathrm{CD}^{+}$, and $\gamma \delta \mathrm{TCR}^{+}$ cell responses and generate memory $\mathrm{T}$ and $\mathrm{B}$ cells, despite blocking of primary humoral responses by maternal Ig (Endsley et al., 2003, 2004). These results suggest that although maternal Ig may block endogenous Ig production, B cells retain other functional capacities (i.e., differentiation into memory $B$ cells).

The importance of different $\mathrm{B}$ cell populations during the development of an immune response and throughout ontogeny is not understood well. The predominant $\mathrm{B}$ cell population in human fetal life is the $\mathrm{CD} 5^{+} \mathrm{B}$ cell and the proportion of this B cell subset decreases with age (Berland and Wortis, 2002; Dono et al., 2004). The $\mathrm{CD}^{+} \mathrm{B}$ cells are thought to produce antibodies that have low affinity and broad specificity (Berland and Wortis, 2002; Dono et al., 2004). Evidence suggests that the CD5 molecule may play a role in cell signaling (Jyonouchi et al., 1990). In addition, bovine CD5 ${ }^{-} \mathrm{B}$ cells can be induced to express CD5 upon B cell receptor crosslinking (Haas and Estes, 2000).

Several cell-surface molecules play important roles in $\mathrm{B}$ cell activation and immunoglobulin production. Expression of CD25 ( $\alpha$-chain of IL-2r) on B cells increases upon activation and is higher on memory than on naïve B cells (Tangye et al., 2003; Arens et al., 2004). Expression of CD21 forms a complex with CD19 and CD81 to form the B cell coreceptor. Coligation of the coreceptor complex with the $\mathrm{B}$ cell receptor reduces the amount of antigen required for B cell activation by 10 to 100 -fold (Carroll and Prodeus, 1998). The CD40 is constitutively expressed on B cells, and binding with its ligand CD40L induces isotype switching, increased CD25 expression, and enhanced major histocompatibility class (MHC) II and CD80 expression (Clatza et al., 2003; McHeyzer-Williams and McHeyzer-Williams, 2005). Expression of MHC class II and CD80 on B cells is necessary for antigen presentation to and costimulation of $\mathrm{CD}^{+} \mathrm{T}$ cells, respectively (Collins et al., 2005; Drozina et al., 2005). B-B2 is a B cell-restricted molecule with no apparent human orthologue. B-B2+ ileal intraepithelial lymphocytes from calves coexpress sIgM and CD21, but rarely coexpress CD5 (Wyatt et al., 1999). In addition, it is well known that adhesion molecules, such as CD11a/18, are necessary for B cell trafficking throughout the lymph system (Martz, 1987). Because all of these activation molecules have important roles in B cell function and immunoglobulin production, one goal was to determine whether B cells from vaccinated neonatal calves have similar expression of these im- portant activation molecules in response to the 2 different antigens OVA and BCG.

The current study characterized the composition and function of $B$ cell populations from neonatal calves vaccinated with OVA and BCG. Ovalbumin was selected as an antigen not encountered in the natural environment of cattle and that elicits Ig responses in neonatal and adult cattle that are similar in magnitude (Husband and Lascelles, 1975). Mycobacterium bovis, strain BCG was utilized because it induces an Ig response in adult cattle but not in colostrum-fed neonatal calves (Nonnecke et al., 2005), presumably due to blocking maternal Ig resulting from exposure of dams to environmental mycobacteria. Potential effects of BCG vaccination on OVA-specific Ig responses were also considered.

\section{MATERIALS AND METHODS}

\section{Preparation of OVA and BCG}

Crystallized OVA (Sigma Chemical Co., St. Louis, MO) was dissolved 2:1 ( $\mathrm{mg} / \mathrm{mL})$ in sterile PBS and then diluted 1:1 (vol/vol) in incomplete Freund's adjuvant (Immunolon). The mixture was emulsified and administered to calves within an hour of preparation. Calves were vaccinated with $4 \mathrm{~mL}$ of adjuvanted OVA (1mg/ $\mathrm{mL}$ ).

Mycobacterim bovis BCG (Pasteur strain) was grown in Middlebrook's 7H9 media supplemented with $10 \%$ oleic acid-albumin-dextrose complex (Difco, Detroit, MI) plus $0.05 \%$ Tween 80 (Sigma) as described for virulent M. bovis (Bolin et al., 1997). Mid log-phase growth bacilli were pelleted by centrifugation at $750 \times g$, washed twice with PBS (0.01 $M$, ph 7.2), and diluted to the appropriate cell density in $2 \mathrm{~mL}$ of PBS. Bacilli were enumerated by serial dilution plate-counting on Middlebrook's 7H11 selective media (Becton Dickinson, Cockeysville, MD). At 3 wk of age, calves were vaccinated with $10^{7} \mathrm{cfu}$ of $M$. bovis BCG.

\section{Vaccination Schedule for Experiment 1}

Holstein bull calves $(n=6)$ were acquired at $<4$ d of age from a single herd and housed at the National Animal Disease Center (NADC), ARS, USDA. At time of birth calves received $3.9 \mathrm{~L}$ each of colostrum obtained from the source herd. At 3 wk of age, all 6 calves were vaccinated subcutaneously in the midcervical region on the left side of the neck with $4 \mathrm{mg}$ of OVA. On the same day, a subset of calves $(n=3)$ was vaccinated subcutaneously in the midcervical region on the right side of the neck with BCG. At 5 wk of age, all calves $(\mathrm{n}=6)$ were revaccinated with OVA $(4 \mathrm{mg})$. 


\section{Vaccination Schedule for Experiment 2}

Holstein bull calves $(\mathrm{n}=24)$ were acquired at $<5 \mathrm{~d}$ of age from a single herd and housed at the NADC. At time of birth, calves received $3.9 \mathrm{~L}$ each of colostrum obtained from the source herd. At 3 wk of age, all calves $(\mathrm{n}=24)$ were vaccinated subcutaneously in the midcervical region on the left side of the neck with OVA (4 mg). On the same day, all calves $(\mathrm{n}=24)$ were vaccinated subcutaneously in the midcervical region on the right side of the neck with BCG. At $5 \mathrm{wk}$ of age (14 d after primary sensitization), calves were revaccinated with OVA $(4 \mathrm{mg})$. At $7 \mathrm{wk}$ of age, a subset of calves $(\mathrm{n}=6)$ was euthanized and superficial cervical lymph nodes from both sides of the neck were harvested.

\section{Blood Collection and Mononuclear Cell Recovery and Enrichment}

Peripheral blood was collected from calves in both experiments immediately prior to vaccination ( $3 \mathrm{wk}$ of age) and at 5, 6, and $7 \mathrm{wk}$ of age. Sixty milliliters of blood was collected into $10 \%$ (vol/vol) $2 \times$ acid-citratedextrose [sodium citrate $(77 \mu \mathrm{mol} / \mathrm{L})$, citric acid (38 $\mu \mathrm{mol} / \mathrm{L})$, and dextrose $(122 \mu \mathrm{mol} / \mathrm{L})]$ by jugular venipuncture. Smaller blood samples for analysis of antigen-specific Ig concentrations in serum were collected weekly into $10-\mathrm{mL}$ vacutainers containing no additive (Becton Dickinson, Franklin Lakes, NJ).

Cells used in in vitro Ig production assays were isolated from peripheral blood and enriched by density gradient centrifugation as described previously (Nonnecke et al., 1991). The peripheral blood mononuclear cell (PBMC)-enriched populations were resuspended in RPMI-1640 medium (Gibco Laboratories, Grand Island, NY) supplemented with $25 \mathrm{~m} M$ HEPES buffer, $2 \mathrm{mM}$ L-glutamine (Sigma, St. Louis, MO), antibiotics (100 units $/ \mathrm{mL}$ penicillin and $0.1 \mathrm{mg} / \mathrm{mL}$ streptomycin, Sigma), $50 \mu M$ 2-mercaptoethanol (Sigma), 1\% nonessential amino acids (Sigma), 2\% essential amino acids (Sigma), 1\% sodium pyruvate (Sigma), and 10\% (vol/ vol) heat-inactivated FBS (Hyclone Laboratories Inc., Logan, UT).

\section{Recall and Capture Antigens}

Recall antigens were OVA (Sigma) and $M$. bovis-derived PPD (Pfizer, Kalamazoo, MI). A proteinase Kdigested whole cell sonicate of $M$. bovis BCG (WCSPK), used as capture antigen in ELISA, was prepared as described previously (Nonnecke et al., 2005).

\section{Measurement of Ig in Serum and in Culture Supernatants}

Antigen-specific $\operatorname{IgG}_{1}$ and $\operatorname{IgG}_{2}$ concentrations were determined for serum samples collected weekly before and after vaccination. The OVA-specific and WCS-PKspecific Ig concentrations in supernatants from nonstimulated and antigen-stimulated PBMC cultures were evaluated. Cells were from blood samples collected 2,3 , and 4 wk after primary vaccination. Using 96 -well microtiter plates, triplicate cultures were seeded with $2 \times 10^{5}$ cells and were not stimulated (media only), stimulated with OVA $(10 \mu \mathrm{g} / \mathrm{mL})$, or stimulated with PPD $(10 \mu \mathrm{g} / \mathrm{mL})$. Cultures were incubated for $8 \mathrm{~d}$ at $39^{\circ} \mathrm{C}$ in a humidified atmosphere with $5 \% \mathrm{CO}_{2}$. Supernatants harvested from centrifuged $(400 \times g, 5 \mathrm{~min})$ plates were stored at $-80^{\circ} \mathrm{C}$ until analyzed.

The relative amounts of Ig to OVA and WCS-PK in serum and in culture supernatants were determined by a capture ELISA. The concentration of OVA used in the ELISA was $1.56 \mu \mathrm{g} / \mathrm{mL}$ diluted in PBS. The concentration of WCS-PK used in the ELISA was $40 \mu \mathrm{g} / \mathrm{mL}$ diluted in carbonate/bicarbonate coating buffer $(\mathrm{pH}$ 9.6). Microtiter plates (96-well; Immulon II, Dynatech) were coated with OVA or WCS-PK (100 $\mu \mathrm{L} /$ well). Plates, including control wells containing coating buffer or PBS alone, were incubated for $15 \mathrm{~h}$ at $4^{\circ} \mathrm{C}$. Plates were washed $3 \times$ with PBS with $0.05 \%$ Tween 20 (PBST; $200 \mu \mathrm{L} /$ well) and blocked with a commercial milk diluent/blocking solution $(200 \mu \mathrm{L} /$ well; Kirkegaard and Perry Laboratories, Gaithersburg, MD). After incubation for $1 \mathrm{~h}$ at $37^{\circ} \mathrm{C}$ in the blocking solution, wells were washed in PBST and test sera were added to wells (100 $\mu \mathrm{L} /$ well). Test and control sera were diluted in PBS containing $0.1 \%$ gelatin. Optimal dilutions of test sera were determined by evaluation of the reactivity of 2 -fold serial dilutions ranging from 1:6 to 1:800. Supernatants were not diluted. After incubating for $20 \mathrm{~h}$ at $4^{\circ} \mathrm{C}$ with test samples, wells were washed with PBST and incubated for $1 \mathrm{~h}$ at $37^{\circ} \mathrm{C}$ with horseradish peroxidase-conjugated antibovine IgG heavy and light chains (Kirkegaard and Perry Laboratories) in PBS plus $0.1 \%$ gelatin. Wells were then washed with PBST and incubated for $4.5 \mathrm{~min}$ at room temperature with substrate $\left(3,3^{\prime} 5,5^{\prime}\right.$ tetramethylbenzidine; Kirkegaard and Perry Laboratories). The reaction was stopped by addition of sulfuric acid $(0.18 M)$ and absorbances $(450 \mathrm{~nm})$ of individual wells measured (ELISA plate reader, Molecular Devices, Menlo Park, CA). The change in optical density readings was calculated by subtracting the mean optical density readings for wells receiving coating buffer or PBS alone from the mean optical density readings for antigen-coated wells receiving the same test sample.

\section{Expression of Activation Molecules on B Cells Isolated from Lymph Nodes}

Mononuclear cells were isolated from superficial cervical lymph nodes by straining through a wire-mesh 
Table 1. Primary and secondary antibodies used in the flow cytometric analysis of cells isolated superficial cervical lymph nodes from vaccinated calves

\begin{tabular}{|c|c|c|c|c|}
\hline $\begin{array}{l}\text { Primary } \\
\text { antibody } \\
\text { specificity }\end{array}$ & Clone & Isotype & Source & $\begin{array}{l}\text { Secondary } \\
\text { antibody }^{1}\end{array}$ \\
\hline sIgM & 3IG73A & $\mathrm{IgG}_{1}$ & $\mathrm{VMRD}^{2}$ & $\alpha \mathrm{IgG}_{1}-\mathrm{PerCP}$ \\
\hline sIgM & PIG45A & $\operatorname{IgG}_{2 b}$ & VMRD & $\alpha \operatorname{IgG}_{2 b^{-}}-\mathrm{Cy} 5$ \\
\hline CD5 & B29A & $\mathrm{IgG}_{2 \mathrm{a}}$ & VMRD & $\alpha \mathrm{IgG}_{2 \mathrm{a}}-\mathrm{PE}$ \\
\hline B-B2 & BAQ44a & IgM & VMRD & $\alpha$ IgM-FITC \\
\hline CD25 & LCTB2A & $\mathrm{IgG}_{3}$ & VMRD & $\alpha \operatorname{IgG}_{3}-$ FITC \\
\hline CD21 & GB25A & $\mathrm{IgG}_{1}$ & VMRD & $\alpha \mathrm{IgG}_{1}-\mathrm{PerCP}$ \\
\hline CD11a/18 & BAT75A & $\operatorname{IgG}_{1}$ & VMRD & $\alpha \operatorname{IgG}_{1}-\mathrm{PerCP}$ \\
\hline CD40 & & $\mathrm{IgG}_{1}$ & D. Mark Estes 3 & $\alpha \mathrm{IgG}_{1}-\mathrm{PerCP}$ \\
\hline CD80 & BBI & IgM & Pharmingen & $\alpha$ IgM-FITC \\
\hline
\end{tabular}

${ }^{1}$ Peridinin chlorophyll protein (PerCP)-conjugated secondary antibody was from Becton Dickinson; phycoerythrin (PE)-conjugated secondary antibody was from Southern Biotechnology Associates, Birmingham, AL; FITC-conjugated secondary antibodies were from Southern Biotechnology Associates; cyanine 5 (Cy5)conjugated secondary antibody was from Caltag Laboratories, Burlingame, CA.

${ }^{2}$ VMRD, Pullman, WA.

${ }^{3}$ AntiCD40 monoclonal antibody generously donated by D. Mark Estes, University of Texas Medical Branch, Galveston.

screen. Cultures ( 6 replicates) in microtiter plates were seeded with $2 \times 10^{5}$ cells. Isolated cells were either not stimulated (media only), or stimulated with OVA (10 $\mu \mathrm{g} / \mathrm{mL})$ or with PPD $(10 \mu \mathrm{g} / \mathrm{mL})$. Cultures were incubated for 3 or $6 \mathrm{~d}$ at $39^{\circ} \mathrm{C}$ in a humidified atmosphere with $5 \% \mathrm{CO}_{2}$.

Primary and secondary antibodies used for flow cytometric-staining are listed in Table 1. Monoclonal primary antibody diluted in PBS containing $0.02 \% \mathrm{NaN}_{3}$ and $1 \%$ inactivated FBS was added to individual wells in $50 \mu \mathrm{L}$ aliquots. Cells were incubated for $15 \mathrm{~min}$ at room temperature and centrifuged $(400 \times g$ at room temperature for $2 \mathrm{~min}$ ). Supernatant was decanted and cells were labeled with $100 \mu \mathrm{L}$ of a cocktail containing 4 secondary isotype-specific antibodies conjugated to fluorochromes (listed in Table 1). Secondary antibodies were diluted in PBS containing $0.02 \% \mathrm{NaN}_{3}$ and $1 \%$ inactivated FBS. Cells were incubated for $15 \mathrm{~min}$ at room temperature in the dark and then centrifuged as described above. Cells were resuspended in $200 \mu \mathrm{L}$ of FacsLyse buffer (Becton Dickinson, San Jose, CA) and stored in the dark at $4^{\circ} \mathrm{C}$ until examined on the flow cytometer. Ten thousand cells exhibiting light scattering properties consistent with bovine mononuclear leukocytes were analyzed. Data were acquired using a BDLSR flow cytometer (Becton Dickinson) with CellQuest (Becton Dickinson) software and were analyzed using FlowJo (Tree Star Inc., San Carlos, CA) software.

\section{Statistical Analysis}

Data were analyzed as a completely randomized design using Statview software (version 5.0, SAS Institute Inc., Cary, NC). Calf served as the experimental unit in the analysis of all data. Serum Ig concentration was analyzed as a split-plot with repeated measures ANOVA. The model included the fixed effects of treatment (OVA only or $M$. bovis BCG with OVA vaccination), time (week after vaccination), and the treatment $\times$ time interaction, and calf was included in the model as the random effect. Fisher's protected-LSD test was applied when effects $(P<0.05)$ and trends $(P<0.10)$ were detected by the model. Activation molecule expression was analyzed as a split-plot with factorial ANOVA. Stimulation (i.e., non-, OVA-, or PPD-stimulated), treatment (OVA only or $M$. bovis BCG with OVA vaccination), and location were included in the model as fixed effects, and calf was included in the model as the random effect. Fisher's protected-LSD test was applied when effects $(P$ $<0.05)$ and trends $(P<0.10)$ were detected by the model.

\section{RESULTS}

\section{Ig Responses to OVA and BCG Vaccination}

In experiment 1 , OVA vaccination of 3 -wk-old calves elicited OVA-specific $\operatorname{IgG}_{1}$ and $\operatorname{IgG}_{2} 2$ wk after primary vaccination (Figure 1a and 1b). These responses were enhanced 1 wk after revaccination with OVA. Immunoglobulin cross-reactive with the WCS-PK antigen was detected in sera from all calves before vaccination with BCG (Figure 1c and 1d). Vaccination with BCG did not affect $(P>0.1)$ Ig responses to OVA (Figure 1a and $1 \mathrm{~b}$ ) or induce Ig to WCS-PK antigen (Figure 1c and 1d). The amount of WCS-PK-specific $\mathrm{IgG}_{1}$ and $\mathrm{IgG}_{2}$ actually decreased after $B C G$ vaccination. In vitro, $\mathrm{PBMC}$ from calves produced $(P<0.05)$ OVA-specific Ig in response to OVA stimulation but failed to produce $(P>0.1)$ WCS- 

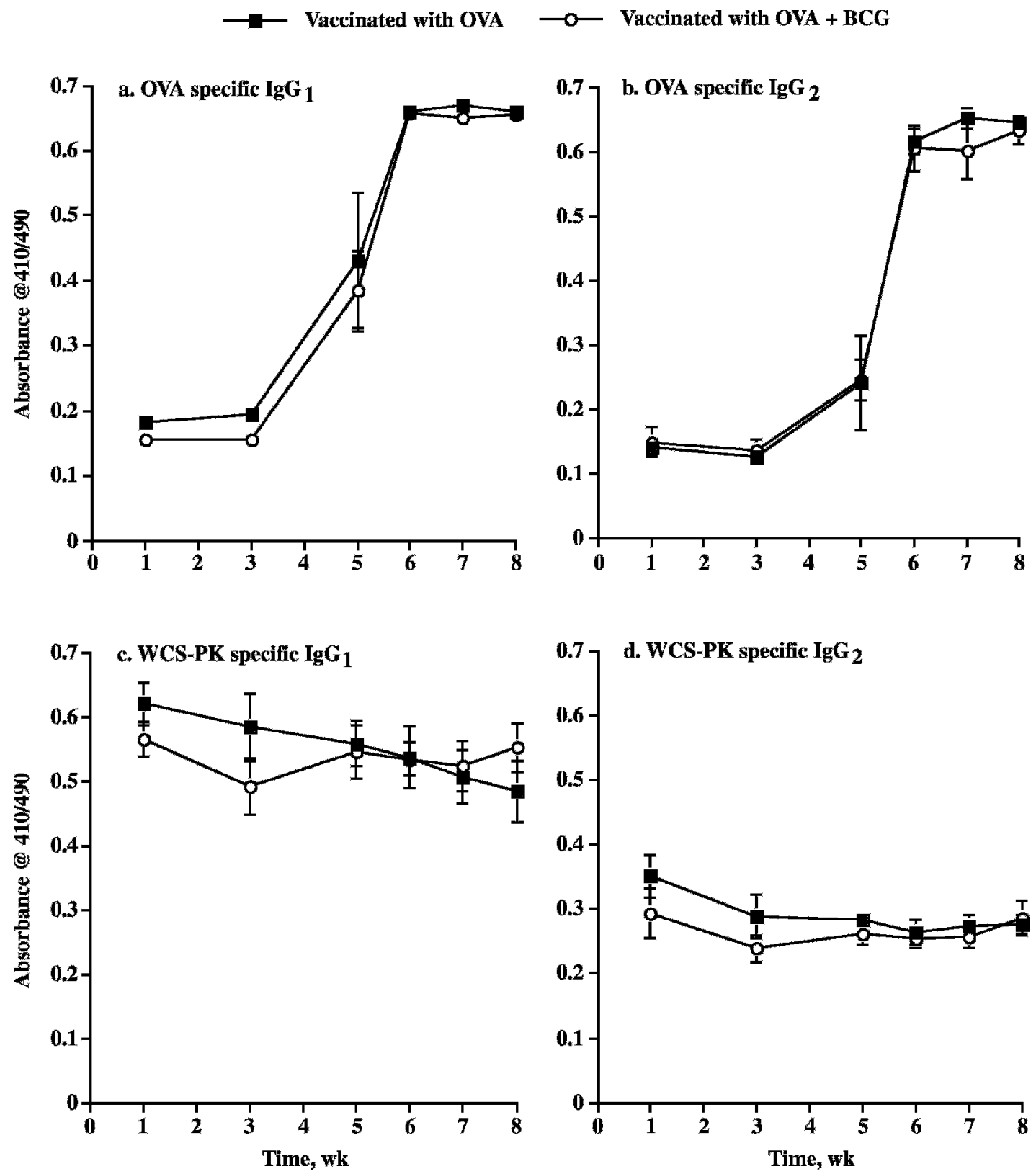

Figure 1. Ovalbumin (OVA) and proteinase K-digested whole cell sonicate of Mycobacterium bovis BCG (WCS-PK) specific Ig in sera from vaccinated calves. Calves were vaccinated with OVA only at 3 and 5 wk of age $(\mathrm{OVA}, \mathrm{n}=3)$ or vaccinated with BCG + OVA at wk 3 and OVA at wk 5 (OVA + BCG; $\mathrm{n}=3$ ). Serum was collected before vaccination at 1 and $3 \mathrm{wk}$ of age, and after vaccination at 5, 6, 7, and 8 wk of age. Absorbances (mean \pm SEM) are shown.

PK-specific Ig when stimulated with PPD (data not shown). Although calves did not produce detectable Ig responses to BCG vaccination, they did have strong cell-mediated immune responses manifested by in vitro IFN- $\gamma$ production by PPD-stimulated PBMC and by in vivo cutaneous delayed-type hypersensitivity to PPD administered intradermally (data not shown).

\section{Activation Molecule Expression on B Cells Stimulated with OVA and PPD}

Expression of activation molecules on $\mathrm{IgM}^{+}$cells and the $\mathrm{CD}^{+} \mathrm{IgM}^{+}$subset in response to OVA and PPD is shown in Figure 2 and Tables 2 to 4 (experiment 2). Percentages of $\mathrm{IgM}^{+}$cells were similar $(P>0.05)$ in 
Left lymph node
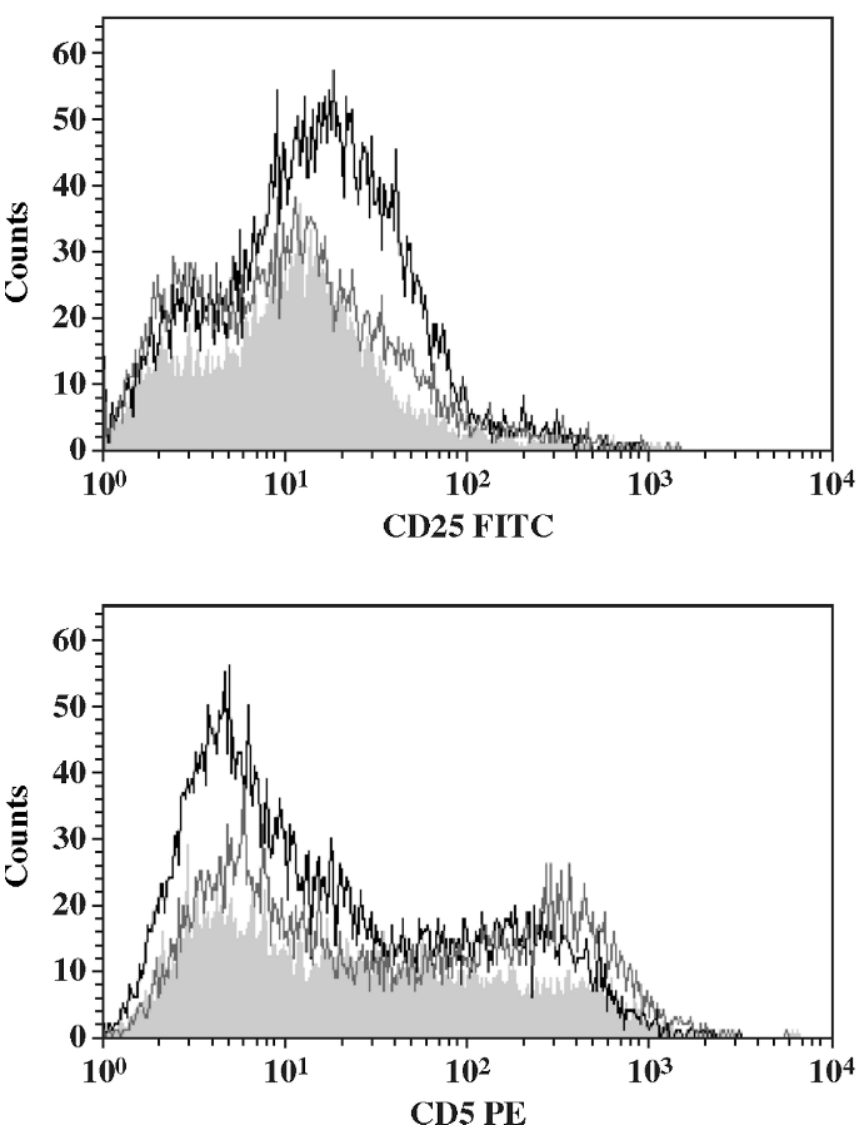

Right lymph node
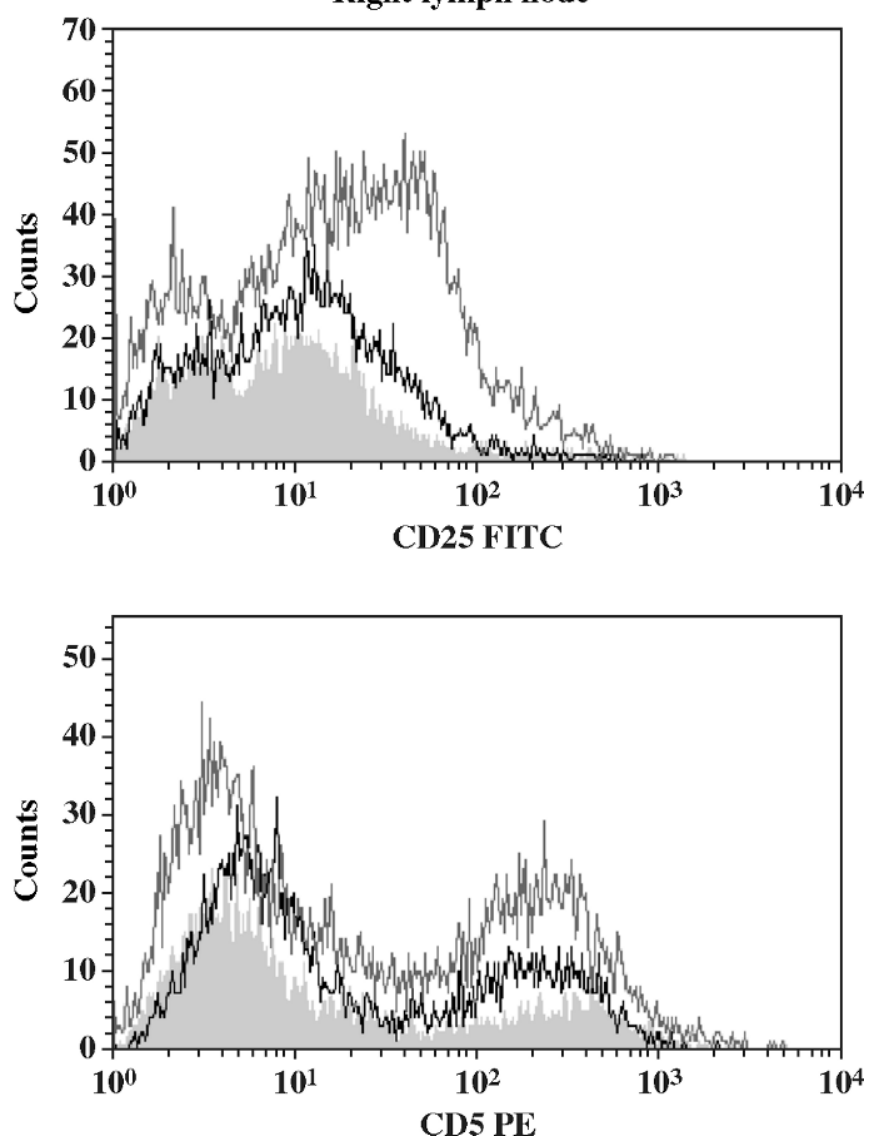

Figure 2. Expression of CD25 and CD5 on B cells $\left(\mathrm{IgM}^{+}\right)$from vaccinated neonatal calves. Mononuclear cells were from the left and right superficial cervical lymph nodes from calves vaccinated with ovalbumin (OVA) on the left side of the neck at 3 and 5 wk of age and with Mycobacterium bovis BCG on the right side of the neck at 3 wk of age. Lymph nodes were from calves $(\mathrm{n}=6)$ euthanized at 7 wk of age. Cells from lymph nodes were nonstimulated (light gray fill), stimulated with OVA (10 mg/mL, black line) or stimulated with PPD (10 $\mathrm{mg} / \mathrm{mL}$, dark gray line) for $6 \mathrm{~d}$.

nonstimulated cultures and in cultures stimulated with OVA or PPD (data not shown).

Stimulation of cells isolated from left superficial cervical lymph nodes with OVA affected expression of activation molecules on $\mathrm{IgM}^{+}$cells and $\mathrm{CD}^{+} \mathrm{IgM}^{+}$cells (Table 2 and Figure 2). Percentages of IgM $^{+}$cells expressing CD5 and mean fluorescence intensity (MFI) of CD5 on $\mathrm{IgM}^{+}$cells were lower $(P<0.05)$ in OVA-stimulated than on cells in nonstimulated cultures (Table 2 and Figure 2). Percentages of $\mathrm{IgM}^{+}$cells expressing B-B2 and MFI of B-B2, CD25, and CD80 were higher $(P<$ 0.05 ) in OVA-stimulated cultures relative to nonstimulated cultures (Table 2 and Figure 2). The MFI of CD21 and $\mathrm{CD} 40$ on IgM $\mathrm{I}^{+}$cells decreased $(P<0.05)$ in response to OVA stimulation. Expression of CD21 was lower on $\mathrm{CD}^{2} 5^{+} \mathrm{IgM}^{+}$cells compared with $\mathrm{CD} 25^{-} \mathrm{IgM}^{+}$cells (data not shown). Expression of MHC-II and CD11a/18 on $\mathrm{IgM}^{+}$cells was not affected $(P>0.05)$ by OVA stimulation. Patterns of activation molecule expression on
OVA-stimulated $\mathrm{CD}^{+} \mathrm{IgM}^{+}$cells were similar to those on the total $\operatorname{IgM}^{+}$cell population. The only exception was an increased $(P<0.05)$ expression of MHC class II antigen expression on $\mathrm{CD}^{+} \mathrm{IgM}^{+}$cells in OVA-stimulated cultures when compared with cells from nonstimulated cultures. Stimulation with PPD did not affect $(P$ $>0.05$ ) expression of CD5, B-B2, CD21, CD25, MHCII, CDlla/18, CD80, or CD40 on $\mathrm{IgM}^{+}$or $\mathrm{CD}^{+} \mathrm{IgM}^{+}$cells isolated from left superficial cervical lymph nodes (Table 2).

Stimulation of right superficial cervical lymph node cells with PPD, however, increased CD25 and CD80 MFI on $\mathrm{IgM}^{+}$and $\mathrm{CD}^{+}{ }^{+} \mathrm{IgM}^{+}$cells (Table 3 and Figure 2). Expression of MHC class II on $\mathrm{CD}^{+}{ }^{+} \mathrm{SIgM}^{+}$cells was higher $(P<0.05)$ on PPD-stimulated cells than on nonstimulated cells. Expression of CD5, B-B2, CD21, $\mathrm{CD} 11 \mathrm{a} / 18$, and $\mathrm{CD} 40$ on $\mathrm{IgM}^{+}$and $\mathrm{CD}^{+} \mathrm{IgM}^{+}$cells was similar $(P>0.05)$ on PPD- and nonstimulated cells (Table 3 and Figure 2). Stimulation with OVA did not affect 
Table 2. Expression of activation molecules on $\operatorname{IgM}^{+} \mathrm{B}$ cells and $\mathrm{CD} 5^{+} \operatorname{IgM}^{+} \mathrm{B}$ cells isolated from left superficial cervical lymph nodes

\begin{tabular}{lrrr}
\hline & & \multicolumn{2}{c}{ Stimulation } \\
\cline { 2 - 4 } Cell phenotype & \multicolumn{1}{c}{ NS } & OVA & PPD \\
\hline IgM B cells & & & \\
\% CD5 positive & $66.20 \pm 2.63^{\mathrm{a}}$ & $49.36 \pm 4.30^{\mathrm{b}}$ & $61.74 \pm 2.15^{\mathrm{a}}$ \\
CD5 MFI & $67.84 \pm 10.89^{\mathrm{a}}$ & $25.32 \pm 6.20^{\mathrm{b}}$ & $45.30 \pm 6.43^{\mathrm{ab}}$ \\
\% B-B2 positive & $37.56 \pm 2.97^{\mathrm{a}}$ & $54.02 \pm 3.21^{\mathrm{b}}$ & $42.04 \pm 2.04^{\mathrm{a}}$ \\
B-B2 MFI & $7.53 \pm 0.68^{\mathrm{a}}$ & $12.05 \pm 1.28^{\mathrm{b}}$ & $8.50 \pm 0.61^{\mathrm{a}}$ \\
CD21 MFI & $4.93 \pm 0.15^{\mathrm{a}}$ & $4.15 \pm 0.23^{\mathrm{b}}$ & $4.69 \pm 0.21^{\mathrm{ab}}$ \\
CD25 MFI & $3.95 \pm 0.30^{\mathrm{a}}$ & $7.05 \pm 0.81^{\mathrm{b}}$ & $4.86 \pm 0.26^{\mathrm{a}}$ \\
MHC-II MFI & $5.56 \pm 0.70$ & $9.22 \pm 1.74$ & $7.03 \pm 0.99$ \\
CD11a/18 MFI & $11.06 \pm 0.91$ & $8.60 \pm 0.93$ & $10.54 \pm 1.02$ \\
CD80 MFI & $4.53 \pm 0.50^{\mathrm{a}}$ & $6.82 \pm 0.54^{\mathrm{b}}$ & $5.32 \pm 0.40^{\mathrm{a}}$ \\
CD40 MFI & $5.80 \pm 0.36^{\mathrm{a}}$ & $4.46 \pm 0.34^{\mathrm{b}}$ & $5.13 \pm 0.34^{\mathrm{ab}}$ \\
CD5 IgM B cells & & & \\
\% B-B2 positive & $17.20 \pm 1.96^{\mathrm{a}}$ & $30.54 \pm 2.48^{\mathrm{b}}$ & $22.70 \pm 1.02^{\mathrm{a}}$ \\
B-B2 MFI & $3.68 \pm 0.23^{\mathrm{a}}$ & $4.76 \pm 0.22^{\mathrm{b}}$ & $4.02 \pm 0.19^{\mathrm{a}}$ \\
CD21 MFI & $4.89 \pm 0.27^{\mathrm{a}}$ & $3.95 \pm 0.23^{\mathrm{b}}$ & $4.50 \pm 0.27^{\mathrm{ab}}$ \\
CD25 MFI & $2.95 \pm 0.15^{\mathrm{a}}$ & $4.96 \pm 0.62^{\mathrm{b}}$ & $3.69 \pm 0.15^{\mathrm{a}}$ \\
MHC-II MFI & $2.84 \pm 0.11^{\mathrm{a}}$ & $4.09 \pm 0.51^{\mathrm{b}}$ & $3.37 \pm 0.21^{\mathrm{ab}}$ \\
CD11a/18 MFI & $14.12 \pm 0.89$ & $4.10 \pm 1.24$ & $14.44 \pm 1.15$ \\
CD80 MFI & $3.27 \pm 0.25^{\mathrm{a}}$ & $4.18 \pm 0.26^{\mathrm{b}}$ & $3.81 \pm 0.25^{\mathrm{ab}}$ \\
CD40 MFI & $5.17 \pm 0.28^{\mathrm{a}}$ & $4.75 \pm 0.39^{\mathrm{ab}}$ \\
\hline
\end{tabular}

${ }^{\mathrm{a}, \mathrm{b}}$ Means within a row with different superscripts differ $(P<0.05)$.

${ }^{1}$ Mononuclear cells were isolated from left superficial cervical lymph nodes from calves vaccinated with ovalbumin (OVA) on the left side of the neck at 3 and 5 wk of age and with Mycobacterium bovis BCG on the right side of the neck at $3 \mathrm{wk}$ of age. Calves $(\mathrm{n}=6)$ were euthanized at $7 \mathrm{wk}$ of age and lymph nodes were harvested. Cells were either nonstimulated (NS) or stimulated with OVA $(10 \mu \mathrm{g} / \mathrm{mL})$ or purified protein derivative (PPD, $10 \mu \mathrm{g} / \mathrm{mL}$ ) for $6 \mathrm{~d}$. Shown are the mean fluorescence intensities of (MFI; \pm SEM) and percentage of $\mathrm{IgM}^{+} \mathrm{B}$ cells and $\mathrm{CD}^{+} \mathrm{IgM}^{+} \mathrm{B}$ cells positive for indicated activation molecules.

Table 3. Expression of activation molecules on $\operatorname{IgM}^{+}$B cells and $\mathrm{CD}^{+} \operatorname{IgM}^{+}$B cells isolated from right superficial cervical lymph nodes

\begin{tabular}{lrrr}
\hline & \multicolumn{3}{c}{ Stimulation $^{1}$} \\
\cline { 2 - 4 } Cell phenotype & \multicolumn{1}{c}{ NS } & OVA & PPD \\
\hline IgM B cells & & & \\
\% CD5 positive & $66.28 \pm 3.73$ & $66.15 \pm 2.83$ & $59.98 \pm 3.55$ \\
CD5 MFI & $64.70 \pm 15.09$ & $54.68 \pm 8.49$ & $39.42 \pm 7.42$ \\
\% B-B2 positive & $40.15 \pm 4.38$ & $43.30 \pm 2.84$ & $45.28 \pm 1.96$ \\
B-B2 MFI & $7.85 \pm 0.72$ & $8.26 \pm 0.59$ & $9.56 \pm 0.92$ \\
CD21 MFI & $4.96 \pm 0.12$ & $4.86 \pm 0.22$ & $4.77 \pm 0.23$ \\
CD25 MFI & $4.15 \pm 0.38^{\mathrm{a}}$ & $6.34 \pm 0.27^{\mathrm{a}}$ & $6.12 \pm 0.53^{\mathrm{b}}$ \\
MHC-II MFI & $6.09 \pm 0.98$ & $9.90 \pm 0.55$ & $8.92 \pm 1.83$ \\
CD11a/18 MFI & $10.82 \pm 1.07$ & $5.40 \pm 0.37^{\mathrm{ab}}$ & $11.04 \pm 1.35$ \\
CD80 MFI & $4.91 \pm 0.41^{\mathrm{a}}$ & $5.02 \pm 0.16$ & $6.32 \pm 0.53^{\mathrm{b}}$ \\
CD40 MFI & $5.37 \pm 0.12$ & $24.68 \pm 2.50$ & $5.07 \pm 0.21$ \\
CD5 IgM B cells & & $4.50 \pm 0.23$ & \\
\% B-B2 positive & $20.53 \pm 3.27$ & $4.83 \pm 0.33$ & $26.98 \pm 2.10$ \\
B-B2 MFI & $4.03 \pm 0.26$ & $3.53 \pm 0.20^{\mathrm{a}}$ & $4.44 \pm 0.22$ \\
CD21 MFI & $4.88 \pm 0.20$ & $3.30 \pm 0.16^{\mathrm{a}}$ & $4.61 \pm 0.30$ \\
CD25 MFI & $3.13 \pm 0.25^{\mathrm{a}}$ & $12.10 \pm 0.56^{\mathrm{a}}$ & $4.89 \pm 0.44^{\mathrm{b}}$ \\
MHC-II MFI & $2.94 \pm 0.14^{\mathrm{a}}$ & $4.08 \pm 0.23^{\mathrm{ab}}$ & $14.95 \pm 0.42^{\mathrm{b}}$ \\
CD11a/18 MFI & $13.30 \pm 1.02^{\mathrm{ab}}$ & $4.78 \pm 0.24$ & $4.65 \pm 0.33^{\mathrm{b}}$ \\
CD80 MFI & $3.71 \pm 0.25^{\mathrm{a}}$ & $4.72 \pm 0.28$ \\
CD40 MFI & $5.01 \pm 0.21$ & &
\end{tabular}

${ }^{\mathrm{a}, \mathrm{b}}$ Means within a row with different superscripts differ $(\mathrm{P}<0.05)$.

${ }^{1}$ Mononuclear cells were isolated from right superficial cervical lymph nodes from calves vaccinated with ovalbumin (OVA) on the left side of the neck at 3 and $5 \mathrm{wk}$ of age and with Mycobacterium bovis BCG on the right side of the neck at 3 wk of age. Calves $(n=6)$ were euthanized at 7 wk of age and lymph nodes were harvested. Cells were nonstimulated (NS) or stimulated with OVA $(10 \mu \mathrm{g} / \mathrm{mL})$ or purified protein derivative (PPD, $10 \mu \mathrm{g} / \mathrm{mL}$ ) for $6 \mathrm{~d}$. Shown are the mean fluorescence intensities of (MFI; \pm SEM) and percentage of $\mathrm{IgM}^{+} \mathrm{B}$ cells and $\mathrm{CD}^{+} \mathrm{IgM}^{+} \mathrm{B}$ cells positive for indicated activation molecules. 
Table 4. Effects of location (left vs. right superficial cervical lymph node) on expression of activation molecules by ovalbumin (OVA)stimulated $\mathrm{sIgM}^{+}$cells

\begin{tabular}{lrr}
\hline & \multicolumn{2}{c}{ Location of lymph node ${ }^{1}$} \\
\cline { 2 - 3 } Cell phenotype & \multicolumn{1}{c}{ Left } & \multicolumn{1}{c}{ Right } \\
\hline OVA-stimulated & & \\
\% CD5 positive & $49.36 \pm 4.30$ & $66.15 \pm 2.83^{*}$ \\
CD5 MFI & $25.32 \pm 6.20$ & $54.68 \pm 8.49^{*}$ \\
$\%$ B-B2 positive & $54.02 \pm 3.21$ & $43.3 \pm 2.84^{*}$ \\
B-B2 MFI & $12.05 \pm 1.28$ & $8.26 \pm 0.59^{*}$ \\
CD21 MFI & $4.15 \pm 0.23$ & $4.86 \pm 0.22^{*}$ \\
CD25 MFI & $7.05 \pm 0.81$ & $4.58 \pm 0.27^{*}$ \\
MHC-II MFI & $9.22 \pm 1.74$ & $6.34 \pm 0.78$ \\
CD11a/18 MFI & $8.60 \pm 0.93$ & $9.90 \pm 0.55$ \\
CD80 MFI & $6.82 \pm 0.54$ & $5.40 \pm 0.37$ \\
CD40 MFI & $4.46 \pm 0.34$ & $5.02 \pm 0.16$ \\
\hline
\end{tabular}

${ }^{1}$ Mononuclear cells were isolated from superficial cervical lymph nodes from calves vaccinated with OVA on the left side of the neck at 3 and 5 wk of age and with Mycobacterium bovis BCG on the right side of the neck at $3 \mathrm{wk}$ of age. Calves $(n=6)$ were euthanized at 7 wk of age, and lymph nodes were harvested. Cells from lymph nodes were stimulated with OVA $(10 \mu \mathrm{g} / \mathrm{mL})$ for $6 \mathrm{~d}$. Shown are the mean fluorescence intensities (MFI; \pm SEM) and percentage of $\mathrm{IgM}^{+}$or $\mathrm{CD}^{+}{ }^{+} \mathrm{IgM}^{+}$cells positive for indicated activation molecules.

$*$ Means within a row differ $(P \leq 0.05)$.

$(P>0.05)$ expression of CD5, B-B2, CD21, CD25, MHCII, CDlla/18, CD80, or CD40 on $\mathrm{IgM}^{+}$or $\mathrm{CD}^{+} \mathrm{IgM}^{+}$cells isolated from right superficial cervical lymph nodes (Table 3 and Figure 2).

Lymph node location (i.e., left vs. right superficial cervical lymph node) did not affect activation molecule expression on $\mathrm{IgM}^{+}$cells in nonstimulated cultures (data not shown). Location did affect expression of activation molecules in IgM $\mathrm{Ig}^{+}$cells in OVA-stimulated cultures (Table 4). Expression of B-B2 and CD25 was higher $(P<0.05)$ on $\mathrm{IgM}^{+}$OVA stimulated cells from the left lymph node than from the right lymph node. Conversely, expression of CD5 and CD21 was lower $(P<$ 0.05 ) on OVA-stimulated IgM ${ }^{+}$cells from the left lymph node than from the right lymph node. Expression of CD5, B-B2, CD21, CD25, MHC-II, CDlla/18, CD80, or CD40 on IgM $^{+}$cells in PPD-stimulated cultures was not affected $(P>0.05)$ by lymph node location (data not shown).

\section{DISCUSSION}

These results demonstrate that in vitro stimulation of lymph node cells draining BCG vaccination sites results in increased expression of CD25 and CD80 on PPD-stimulated $\operatorname{IgM}^{+}$cells. Despite these findings, serum Ig levels to $M$. bovis antigens did not increase in response to $\mathrm{BCG}$ vaccination. The $\mathrm{PPD}$-stimulated $\mathrm{IgM}^{+}$cells were relatively unresponsive compared with OVA-stimulated $\operatorname{IgM}^{+}$cells. It has been shown that memory $\mathrm{B}$ cells are generated in young calves receiving bovine viral diarrhea virus vaccine, despite blocking of primary responses by maternally derived Ig (Endsley et al., 2003, 2004). This suggests that although maternal Ig blocks endogenous Ig production, B cells are still activated. In the case of BCG, it is postulated that several factors exist to influence efficacy, in addition to maternal Ig, including previous exposure to environmental mycobacteria, nutritional status, and geographic latitude (Wilson, 2000). In addition it can be postulated that activation by antigen-specific $\mathrm{T}$ cells may have influenced in vitro expression patterns of surface activation molecules on B cells in the present study. Although it is tempting to speculate that antigen-specific, memory B cells were generated by BCG and OVA vaccination, further studies using in vivo and in vitro dye-tracking assays or sorting of lymphocyte subsets are warranted to delineate the responding cell populations. However, alterations induced in response to antigen stimulation in vitro likely mimic natural responses within lymphoid centers of the host. Thus, increased CD25 and CD80 expression by B cells in lymphoid centers would favor B cell responsiveness to nearby cells and antigen.

Results support research by others (Husband and Lascelles, 1975) demonstrating that the neonatal calf possesses the capacity to produce Ig to antigens not present in the natural environment of dairy cattle (i.e., OVA). In vitro stimulation of lymph node cells with OVA resulted in decreased CD5 expression on $\mathrm{IgM}^{+}$ cells and decreased $\mathrm{CD}^{+} \mathrm{IgM}^{+} \mathrm{B}$ cell percentages. The origin and function of $\mathrm{CD}^{+} \mathrm{B}$ cells in cattle and other species (Berland and Wortis, 2002; Dono et al., 2004) is not firmly established. They may originate in fetal life and produce polyreactive antibodies with low affinity and broad specificity (Berland and Wortis, 2002; Dono et al., 2004). The prevalence of $\mathrm{CD}^{+} \mathrm{B}$ cells in the peripheral immune system of ruminant animals (i.e., cattle and sheep) is much higher than in mice and humans (Berland and Wortis, 2002). Because CD5 ${ }^{+} \mathrm{B}$ cells are fetal-derived, nonclonal, and producers of polyreactive antibodies, this subset would be expected to decrease in antigen-stimulated mononuclear cell populations from vaccinated calves. Our data suggest that B-B2, CD21, CD25, CD40, and CD80 expression on the $\mathrm{CD}^{+} \mathrm{B}$ cell subset is similar to the general B cell population. However, expression of MHC class II increased on $\mathrm{CD}^{+} \mathrm{IgM}^{+}$cells, but not on other $\mathrm{IgM}^{+} \mathrm{B}$ cells following antigenic stimulation, suggesting that this subset may respond differently to antigenic stimulation.

In vitro stimulation of superficial cervical lymph node cells with OVA resulted in increased $\mathrm{B}-\mathrm{B}^{+} \mathrm{IgM}^{+}$cell percentages and MFI of B-B2. Stimulation of the same population with $\mathrm{PPD}$ was not associated with any changes in $\mathrm{B}-\mathrm{B} 2{ }^{+} \mathrm{IgM}^{+}$cell percentages. The B-B2 mole- 
cule is unique to bovine $\mathrm{B}$ cells and has no known human orthologue. B-B2 ${ }^{+}$ileal intraepithelial lymphocytes (IEL) from calves coexpress IgM and CD21, but rarely CD5 (Wyatt et al., 1999). Function and phenotype of IEL, which are predominantly $\mathrm{T}$ cells, in the gut are very different from other lymphocyte subsets (Cheroutre, 2004). Therefore, it is not surprising that expression of B-B2, IgM, CD21, and CD5 on B cells differ from that on IEL. Functional aspects of B-B2 ${ }^{+} \mathrm{B}$ cells have not been described extensively (Wyatt et al., 1999). In the present study, the increased B-B2 expression and concomitant induction of measurable Ig in response to antigen (i.e., OVA) suggest that the $\mathrm{B}-\mathrm{B} 2^{+}$ $\mathrm{B}$ cell subset may play a role in Ig production in vaccinated calves. Further investigation on the role of B-B2 ${ }^{+}$ $\mathrm{B}$ cells in the production of Ig is still needed.

Effects of OVA and BCG vaccination on B cells appeared to be localized within the lymph node draining the vaccination site. The $B$ cells isolated from superficial cervical lymph nodes from the opposite side of the neck were generally unresponsive to antigenic stimulation. Thus, BCG vaccination appears not to modulate $\mathrm{B}$ cell response to the unrelated antigen, OVA.

Expression of CD25, MHC class II, and CD80 on $\mathrm{IgM}^{+}$ cells in OVA- and PPD-stimulated mononuclear cell cultures was similar. Whereas CD21 and CD40 expression on $\operatorname{IgM}^{+}$B cells decreased in response to OVA, expression of these molecules was unaffected by PPD. Why CD21 and CD40 expression on $\mathrm{IgM}^{+} \mathrm{B}$ cells was unaffected by PPD is not known. Studies on the role that colostrum-derived Ig cross-reactive with BCG may have on the expression of these activation molecules on antigen-stimulated B cells are needed. The interaction of constitutively expressed CD40 on B cells with CD40L on $\mathrm{T}_{\text {helper }}$ cells is critical for the development of $\mathrm{CD} 4^{+}$ $\mathrm{T}$ cell effector functions, including support for B-cell differentiation and Ig class switching (Grewal and Flavell, 1996). The significance of CD40 and CD21 downregulation on $\mathrm{B}$ cells in OVA-stimulated cultures is not known. Because the ability to produce OVA-specific Ig was associated with CD40 and CD21 downregulation, decreased expression of these molecules may indicate $\mathrm{B}$ cell maturation. In addition, CD21 expression was lower on $\mathrm{CD}_{25} 5^{+}$than on CD25-B cells. The percentages of $\mathrm{CD}_{25}{ }^{+} \mathrm{B}$ cells, however, were similar in OVA- and PPD-stimulated cultures (data not shown).

\section{CONCLUSIONS}

In conclusion, vaccination of 3 -wk-old calves with OVA elicited measurable Ig responses that were amplified by revaccination at 5-wk of age. Vaccination with $\mathrm{BCG}$, in contrast, did not affect existing levels of Ig to mycobacteria-specific antigen. Recall responses to OVA by $\mathrm{B}$ cells isolated from lymph nodes draining the site of OVA vaccination were characterized by decreased CD5, CD21, and CD40 expression and increased BB2, CD25, and CD80 expression. Recall responses of B cells isolated from lymph nodes draining the site of $\mathrm{BCG}$ vaccination to $\mathrm{PPD}$ were characterized by increased CD25 and CD80 expression. Interestingly, B cells isolated from lymph nodes draining the vaccination site, but not from the opposing side of the body, responded to antigenic stimulation, suggesting initiation and maturation of adaptive immune responses remain localized. These data indicate that the responsiveness of $\mathrm{B}$ cells in neonatal calves is dependent on the nature of the vaccine. Future studies (e.g., using colostrum-deprived calves) considering the effects of the colostrum-derived Ig on responses of preruminant calves to early vaccination and infection are warranted.

\section{ACKNOWLEDGMENTS}

Authors thank N. Eischen, D. McDorman, J. Mentele and B. Pesch at the NADC and A. Maue at University of Missouri for technical support; and E. Miller, A. Moser, and P. Amundson for excellent animal care.

\section{REFERENCES}

Aldridge, B. M., S. M. McGuirk, and D. P. Lunn. 1998. Effect of colostral ingestion on immunoglobulin-positive cells in calves. Vet. Immunol. Immunopathol. 62:51-64.

Arens, R., M. A. Nolte, K. Tesselaar, B. Heemskerk, K. A. Reedquist, R. A. van Lier, M. H. van Oers. 2004. Signaling through CD70 regulates B cell activation and IgG production. J. Immunol. 173:3901-3908.

Berland, R., and H. H. Wortis. 2002. Origins and functions of B-1 cells with notes on the role of CD5. Annu. Rev. Immunol. 20:253-300.

Bolin, C. A., D. L. Whipple, K. V. Khanna, J. M. Risdahl, P. K. Peterson, and T. W. Molitar. 1997. Infection of swine with Mycobacterium bovis as a model for human tuberculosis. J. Infect. Dis. 176:1559-1566.

Carroll, M. C., and A. P. Prodeus. 1998. Linkages of innate and adaptive immunity. Curr. Opin. Immunol. 10:36-40.

Cheroutre, H. 2004. Starting at the beginning: New perspectives on the biology of mucosal T cells. Annu. Rev. Immunol. 22:217-246.

Clatza, A., L. C. Bonifaz, D. A. Vignali, and J. Moreno. 2003. CD40induced aggregation of MHC class II and CD80 on the cell surface leads to an early enhancement in antigen presentation. J. Immunol. 171:6478-6487.

Collins, M., V. Ling, and B. M. Carreno. 2005. The B7 family of immune-regulatory ligands. Genome Biol. 6:223.

Dono, M., G. Cerruti, and S. Zupo. 2004. The CD5+ B-cell. Int. J. Biochem. Cell Biol. 36:2105-2111.

Drozina, G., J. Kohoutek, N. Jabrane-Ferrat, and B. M. Peterlin. 2005. Expression of MHC II genes. Curr. Top. Microbiol. Immunol. 290:147-170.

Endsley, J. J., J. F. Ridpath, J. D. Neill, M. R. Sandbulte, and J. A. Roth. 2004. Induction of $\mathrm{T}$ lymphocytes specific for bovine viral diarrhea virus in calves with maternal antibody. Viral Immunol. $17: 13-23$.

Endsley, J. J., J. A. Roth, J. Ridpath, and J. Neill. 2003. Maternal antibody blocks humoral but not $\mathrm{T}$ cell responses to BVDV. Biologicals $31: 123-125$. 
Grewal, I. S., and R. A. Flavell. 1996. The role of CD40 ligand in costimulation and T-cell activation. Immunol. Rev. 153:85-106.

Haas, K. M., and D. M. Estes. 2000. Activation of bovine b cells via surface immunoglobulin $\mathrm{m}$ cross-linking or CD40 ligation results in different B-cell phenotypes. Immunology 99:272-278.

Husband, A. J., and A. K. Lascelles. 1975. Antibody responses to neonatal immunisation in calves. Res. Vet. Sci. 18:201-207.

Jyonouchi, H., R. M. Voss, and R. A. Good. 1990. Up-regulation and down-regulation of cell surface and MRNA expression of CD5 antigen by various humoral factors on murine $70 \mathrm{z} / 3$ pre-B cell leukemia cell line: IL-4 down-regulates CD5 antigen expression. Cell. Immunol. 130:66-78.

Martz, E. 1987. LFA-1 and other accessory molecules functioning in adhesions of T and B lymphocytes. Hum. Immunol. 18:3-37.

McHeyzer-Williams, L. J., and M. G. McHeyzer-Williams. 2005. Antigen-specific memory B cell development. Annu. Rev. Immunol. 23:487-513.
Nonnecke, B. J., S. T. Franklin, and S. L. Nissen. 1991. Leucine and its catabolites alter mitogen-stimulated DNA synthesis by bovine lymphocytes. J. Nutr. 121:1665-1672.

Nonnecke, B. J., W. R. Waters, M. R. Foote, M. V. Palmer, B. L. Miller, T. E. Johnson, H. B. Perry, and M. A. Fowler. 2005. Development of an adult-like cell-mediated immune response in calves after early vaccination with Mycobacterium bovis bacillus Calmette-Guerin. J. Dairy Sci. 88:195-210.

Tangye, S. G., D. T. Avery, E. K. Deenick, and P. D. Hodgkin. 2003. Intrinsic differences in the proliferation of naive and memory human B cells as a mechanism for enhanced secondary immune responses. J. Immunol. 170:686-694.

Wilson, M. E. 2000. Applying experiences from trials of bacille Calmette-Guerin vaccine. Clin. Infect. Dis. 30(Suppl. 3):S262-S265.

Wyatt, C. R., W. J. Barrett, E. J. Brackett, W. C. Davis, and T. E. Besser. 1999. Phenotypic comparison of ileal intraepithelial lymphocyte populations of suckling and weaned calves. Vet. Immunol. Immunopathol. 67:213-222. 